\title{
小学校複合化施設における児童の火災避難行動に関する研究 RESEARCH ON BEHAVIOR OF CHILDREN DURING FIRE ESCAPE AT SCHOOL-COMMUNITY CONPLEXES
}

\author{
鈴木賢一*, 建部謙 治**, 吉 岡 竜已*** \\ Ken-ichi SUZUKI, Kenii TATEBE and Tatsumi YOSHIOKA
}

\footnotetext{
The purpose of this paper is to clarify the influences of children's space perception and fire safety knowledge on evacuation behavior in school-community complexes.

The results are summarized as follows;

1) The ratio of routes away from the fire increase in proportion with the age of children.

2 ) More than $80 \%$ of the children do not understand whether to open or shut windows in a fire.

3 ) Having space perception influences the judgment of a correction to some extent.

4) Most children in a fire during recess tend to act in a group with their teachers.
}

Keywords: school complex, fire escape, elementary school, space perception, disaster prevention education 学校複合化、火災避難、小学校、空間認知、防災教育

\section{1. 研究の概要}

\section{1 研究の背累と目的}

小学校で通常行われる火災避難訓練は、教師が児童を集団引率 する避難訓練であることが多い。この場合児童は教師の指示に従 うだけで、避難に必要な判断能力を厳しく問われない。しかし実 際の火災は、休み時間や下校時など教師が身近に不在の状況下で も起こりうることであり、児童が自ら状況判断し単独で避難しな ければならないことも想定する必要がある。筆者らが標淮的平面 プランの小学校を対象として実施した単独避難を想定した火炎避 難行動調査からは、一部児童に不適切な行動がみられることが明 らかになった文い〜4)。そこでは児童の学校空間認知程度が適切な 避難経路選択に関連していることもわかった。

さて、東京都心などでは、学校の統廃合を機に土地の有效利用 を図るため、図書館や老人施設など他の公共施設を複合させた施 設 (以下、学校複合化施設注 1 ) と呼ぶ) が建てられるようになっ た。この場合、単独に建つ従来の学校の避難条件と異なり、建物 が複合化・高層化することによる建築構成の違い、運営主体の複 数化に伴う防災管理の複雑化など、児童にとってはより避難が難 しくなることが予想される。 本研究はこうした学校複合化の現状をふまえ、複合化された学
校における子どもの建築空間の認知状況ならびに火災に対する知 識や避難行動特性などを把握し、学校複合化施設特有の火炎避難 に関する論点を明らかにしようとするものである。

\section{2 既往研究}

これまで筆者らは、経路マップ法を用いて小学校における児童 単独の避難の問題点を明らかにするとともに、学校空閒認知や火 災知識・行動判断の違いによる避難経路選択一の影響を分析して きた。しかしながら、いずれも 4 層以下の単独小学校を対象とし たもので、学校複合化施設における児童の避難を扱っていない。

学校複合化の実態については、上野ら文らが東京都における複 合化小・中学校の日常的管理・運営について調查を行っている。 また、斎尾ら文 ${ }^{61}$ は、全国的に地域施設としての公立小・中学校 の機能複合化について調查している。また、複合的大規模施設の 経路探索に関しては、大野ら文7) が、上下移動による経路や方向 の把握に対する影響を実験的に確かめている。

\section{3 研究方法}

研究は、まず東京都区部を対象として小中学校に関連する複合 化施設の概要と建設年次推移を追跡し、その実態を概観した。そ の後、小学校複合化施設の児童を対象とし、基礎的な火災知識、 判断力の程度を調べた。合わせて複合化、高層化された学校複合
* 名古屋市立大学大学院芸術工学研究科 助教授・博士 (工学)

** 愛知工業大学工学部 教授・博上 (工学)

*** 東海工業専門学校 非常勤講師・修士(芸術)
Assoc. Prof., Dept. of Design and Architecture, Nagoya City Univ., Dr. Eng.

Prof., Dept. of Urban Environment, Faculty of Engineering, Aichi Institute of Technology, Dr. Eng.

Part-time Lecturer, Tokai Polytechnic College, M. Art 
化施設の空間の認知程度を調べた。これらはいずれも避難時に適 切な判断をするための基礎的能力の程度を明らかにするものであ る。その後、机上にて避難経路を描かせ、子どもたちの学校複合 化施設における避難行動特性を分析することとした。

\section{4 調查の方法}

東京都区部における学校複合化施設に関する以下の調查を行っ た。いずれも 1998〜99 年に実施した。

1) 東京都内 23 区の教育委員会に対し、ヒアリングまたはアン ケートにより、中学校を含む学校複合化施設の有無と設立年を確 認した。このうち学校校舎と一体化した 11 校の学校複合化施設 を現地訪問し、施設責任者から火災を中心とする防災体制に関す るヒアリングを行った。

2 ）調查協力の得られた小学校複合化施設 6 校の児童に対して以 下の調查を実施した注2)。対象人数は、654人（2年生：179人、 4 年生 : 241 人、 6 年生 : 234 人) である。調查はクラス毎に一 校時を使って、担任が調査マニュアルに従って行った。

(1) 火炎に関する知識と行動調査：火災に関する知識及び火災時 の対応行動についてアンケートにより質問した。

(2) 学校空間の認知度調查: 児童の学校空間認知率注3)を知るた めに、予め用意された学校複合化施設の白紙の平面図に、自分 の知っている室名を書き込む全統制法による調査を行った。

(3) 避難経路調查 : 特定の室からの出火を想定した上で、当該学 校の平面図上に、自分のクラスルームから運動場までの避難経 路を動線で示させた。

\section{5 䩗查方法の検討過程と限界}

1）火災に関する知識、火炎に対する判断・行動について 本研究では火災に関する知識、火災に対する判断・能力に関し、 あらかじめ選択肢を用意したアンケートを行った。これは、回答 能力にばらつきのある $2 \sim 6$ 年生の子どもたちの火災に対する知 識と判断・行動に関して、簡便にある程度精度のそろったデータ を得るためである。アンケート形式については、予備調査の段階 で調查協力を得られた学校サイドと相談しながら修正を加え、最 終判断している。しかし、あらかじめ選択肢を用意することによ り、児童の側に正しい知識が欠如していても正解にたどり着く大 きなヒントを与える、あるいは偶然正解にたどり着く可能性があ り、実際の知識は、アンケートから導きだされる結果よりも差し 引いて判断する必要がある。なお、本調査で用いたアンケートは、 1996 年から 98 年にかけ名古屋市内で 13 校の $2 、 4 、 6$ 年生合計 2,499 名に対して実施したものと同じであり、この結果について は筆者らによる既報、文2) で報告している。

2) 空間認知について

ここで採用した調查方法は、「空間を諗知していること」を「空 間の名称を知っていること」に置き換えて「平面図に室名を書か せる」という方法であり、「室名を書けても空間を認知していな い小あるいはその逆に「室名が書けなくても空間を認知してい る」ことはないかという問題について検証が不十分である。しか し、当調查における「空間を認知していること」を確認する目的 は、(1)火災避難において出火室に近づかない、または出火室を避 けるためにどこが出火室かを理解できる能力の有無を知る、(2)発 達段階に即した防災教育に関連する指導方法を考えるための空間
認知に関する情報を得ることであり、その点に関しては有効なデ 一タを得ることができる。なお、「平面図に室名を記入させる」 調查の検証過程と、標準的平面を有する学校での調査結果につい ては、筆者らによる既報、文3）に詳しい。

3）避難経路の選択について

空間に関する理解力の異なる $2 、 4 、 6$ 年生の児童から、平面 図に避難経路を記入させる方法で有効なデータを得られるかどう かについては、描画の自由度の異なる 3 つの方法について段階的 に検討してきた。白紙に平面図を描かせる自由描画法、建物の外 形線を与える一部統制法、建物の平面図を与える全統制法によっ て得られる結果の精度の比較検討過程を経て、少なくとも 2 年生 でも分析可能なデータを得られるという点で全統制法が優れてい ることを検証してきた。また、実際の火災に近い状況での避難デ ータを得るためには、(1)予告なしの避難訓練による調査、(2)避難 シミュレーターを利用した調查が考えられるが、(1)については調 查実施上の危険性、(2)については試行段階である文8)ことから、 ここでは、平面図上での調查を採用した。ただし、実際の火災現 場においては、混乱した状況下に置いてどのような行動をとるか は予想がつかないという点で、結果からの安易な類推は注意が必 要である。

\section{2.䙡合化の推移と拥査校の概要 \\ 2.1 複合化の推移}

東京都内で学校複合化施設が見られるようになったのは 1960 年代頃からで、当初は幼稚園や学童クラブとの複合といった小規 模なものから始まった。以降 80 年代に至るまで複合化施設数は 40 校程度まで増加した。80 年代に入る頃から単独の学校では見られ ない 5 層以上（地下階を含む）の複合化施設が出現し始める（図 1)。複合される施設の種類や数は、区の事情や方針によっても 異なるが、都の中央に位置する千代田区、中央区、文京区などに は近年 5 層以上に高層、複合化されたものが多い注4)

この調查では、1999 年の時点で東京 23 区のうち 13 区 76 校の 小・中学校が学校複合化施設であるとの回答があった。小学校で 複合化されたものは 73 校（都内の小学校全体の約 8\%にあたる) で、約 $20 \%$ が 5 層を超える建物となっている。この内、学童クラ ブや幼稚園のみが併設されているものが 47 校あり、半数以上は 小規模な施設である。これに対し、中学校の複合化施設はわずか 5 校 (うち2 校は小学校との併設) であった。

\section{2 部查校の概要}

調査対象の 6 校はいずれも小学校と他の公共施設とが建築構成 上一体的なスタイルをとっている。延べ床面積の最も小さい学校 でも $11,000 \mathrm{~m}^{2}$ を超える規模で、最大は $18,000 \mathrm{~m}^{2}$ 超える例も含 まれる(表 1 )。

中央区の 2 校はいずれも 1994 年に竣工したものである。N 小は 地下 2 階地上 9 階で、小学校は地下 1 階から地上 5 階に配置され ている。同一建物の 1-2 階に幼稚園、5-6 階に図書館、7-9 階 に社会教育会館が配置されている。小学校の上下層に他の公共施 設が配置されたものである。D 小は地下 2 階地上 5 階で、このう ち小学校は 2 階以上を占めている。地階に福祉作業所と社会教育 館、1 階に幼稚園があり、小学校の下層に他の施設を複合してい 
ることになる。

千代田区のI 小学校は、本格的複合化施設として 1985 年と比 較的早い時期に完成した。地下 1 階地上 8 階の建物のうち $1-4$ 階を小学校が占める他は、1-2 階に幼稚園・保育所、5 階以上に 教育研究所、区民図書館、社会教育施設などが設置されている。 同区の $\mathrm{S}$ 小、 $\mathrm{T}$ 小は、それぞれ地下 2 階地上 6 階、地下 2 階地上 7 階の規模である。S 小は地上レベルに幼稚園・図書館、5 階には 児童館がある。T 小は $1-2$ 階に図書館と幼稚園、6 階以上は教育 研究所である。港区の K 小は、幼稚園及び中学校と一体化した施 設で地下 1 階地上 4 階の規模である。

\section{3.火災に関する知識と判断力}

\section{1 火災に関する知識}

火災に関する知識として、1）火災に対するイメージ、2）煙 の危険性、3）煙の見通し、4）火災の危険性、5）下階へ避難、 6 ）火災の拡大、7）火炎時の空の開閉、8）火災時の煙の流動 について質問した。ここでは、「空の開閉」と「煙の流動」につ いての結果を取り上げる注5!。

「火事が起きた時に窓はどうするべきか」という問いに対して、 「開ける」「閉める」「わからない」を選択させた（図 2 )。閉め る」という正解涪的を選択できた子どもはいずれの学年も $20 \%$ 前 後で、学年間に大きな差は見られなかった。逆にどの学年も $70 \%$ 前後が「開ける」と答えており、火炎時の窓の開閉に対する知識 は十分とはいえない。開ける」とした児童の理由としては、「救 助を求める」「避難する際に視界を良くするために煙を外に出す」 等である。

「煙の流動」は、火災時に発生する煙が一般的に建物内にどの ように流動拡散するかを尋ねたものである（図 3)。「上部への流 動」「上下同時に流動」「水平方向への流動」「下部への流動」を 選択させた。小学 2 年生では、 $25 \%$ 程度の正解率であるものが、 4 年 6 年となると $70 \%$ 程度まで上がる。前問とは異なり、煙の流 動に関する知識が 4 年生以上では確実に身に付いていることがわ かる。教科における学習と連動した知識と考えることも可能であ る。

この 2 つの設問については、これに関した特別な指導が行なわ れて抢らず、児童によって回答がばらついたものと考えられる。 今後学校では、煙の危険性だけではなく、その流動や処理の仕方 なども配慮し、また防災教育の効果を定期的に確認することが求 められる。

\section{2 火炎に対する判断・行動}

火災に対する判断では、休办時間中に教室にいて火災が発生し たことを知った場合どうするかを聞いている。選択肢は、「即時 に避難」「教室に集合」「指示待ち」「周囲に同調」「教師に報告」

「消火活動」「その他」である。図 4 は各学年別の火災判断を示 したものである。

独自の判断能力が最も高いと考えられる 6 年生について述べる。 6 年生の火災を想定した避難の行動予測で最も多いものは「指示 待ち」の $36 \%$ であった。校内放送や先生からの直接的な指示を待 って行動することを選択したものである。自己判断で行動を起こ

す「即避難」の選択率は $18 \%$ で、ほぼ 5 人に 1 人の割合であ

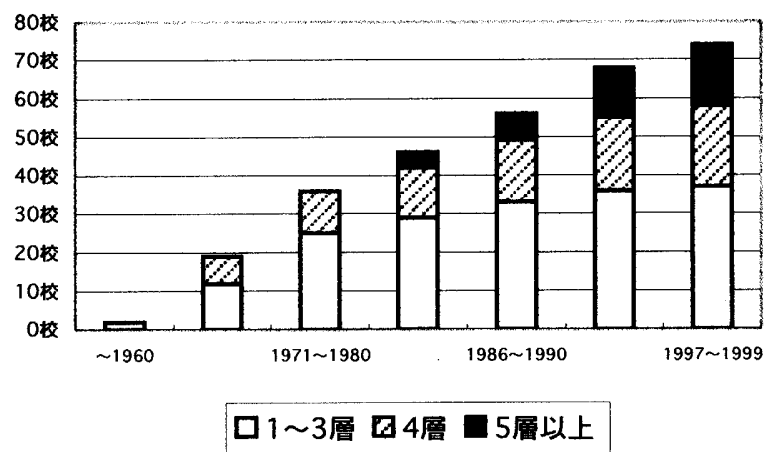

図 1 東京都に㧍ける学校複合化施設の累積数の年代推移

表 1 調查校の概要と調查人数

\begin{tabular}{|c|c|c|c|c|c|c|c|}
\hline 区名 & 学校名 & 竢工年 & 併設旅設 & 略教 & \begin{tabular}{|c|} 
クラス数 \\
榃莗生徒数
\end{tabular} & 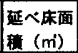 & 班查対策人数 \\
\hline \multirow{2}{*}{ 中央 } & N小 & 1994 & 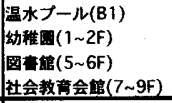 & $\begin{array}{l}\text { 全 } \\
\text { 小体(B2 9F) } \\
\text { 小学校(B1 5F) }\end{array}$ & $\begin{array}{c}11 \text { クラス } \\
333 \text { 人 }\end{array}$ & 18,325 & $\begin{array}{l}2 \text { 年生: } 67 \text { 人 } \\
4 \text { 年生: } 52 \text { 人 } \\
6 \text { 年生: } 33 \text { 人 }\end{array}$ \\
\hline & D小 & 1994 & 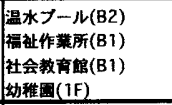 & $\begin{array}{l}\text { 全 体(B2 5F) } \\
\text { 小学校(2 5F) }\end{array}$ & $\mid \begin{array}{c}10 \text { クラス } \\
265 \lambda\end{array}$ & 16,160 & $\begin{array}{l}2 \text { 年生: } 45 \lambda \\
4 \text { 年生: } 56 \hat{\curlywedge} \\
6 \text { 年生: } 44 \text { ᄉ }\end{array}$ \\
\hline \multirow{3}{*}{ 千代田 } & S小 & 1996 & 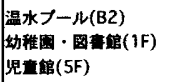 & $\begin{array}{l}\text { 全 体(B2 6F) } \\
\text { 小単校 }(B 1 \sim 6 F)\end{array}$ & $\begin{array}{l}8 \text { クラス } \\
186 \curlywedge\end{array}$ & 15,007 & $\begin{array}{l}2 \text { 年生:29人 } \\
4 \text { 年生:28 } \\
6 \text { 年生: } 36 \text { 人 }\end{array}$ \\
\hline & 1小 & 1985 & 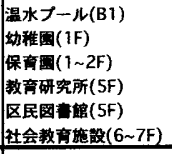 & $\begin{array}{l}\text { 全 } \\
\text { 小体 }(B 1 \sim 8 F) \\
\text { 絭校 }(1 \sim 4 F)\end{array}$ & $\begin{array}{c}12 \text { クラス } \\
296 \lambda\end{array}$ & 11,180 & $\begin{array}{l}4 \text { 年生: } 43 \text { 人 } \\
6 \text { 年生 } 54 \text { 人 }\end{array}$ \\
\hline & T小 & 1998 & 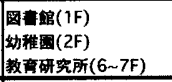 & $\begin{array}{l}\text { 全 体(B2 7F) } \\
\text { 小学校(2 5F) }\end{array}$ & $\begin{array}{l}\text { 8クラス } \\
200 \curlywedge\end{array}$ & 12,874 & $\begin{array}{l}4 \text { 年生: } 27 \text { 人 } \\
6 \text { 年生:40人 }\end{array}$ \\
\hline 港 & K小 & 1996 & 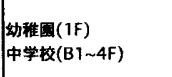 & $\begin{array}{l}\text { 全 体(B1 4F) } \\
\text { 小学校(1 4F) }\end{array}$ & $\begin{array}{l}8 \text { クラス } \\
329 \text { 人 }\end{array}$ & 14,711 & $\begin{array}{l}2 \text { 年生: } 38 \text { 人 } \\
4 \text { 年生: } 35 \text { 人 } \\
6 \text { 年生: } 27 \text { 人 }\end{array}$ \\
\hline
\end{tabular}

6年生(234人) 4年生 (239人)

2年生(179人)

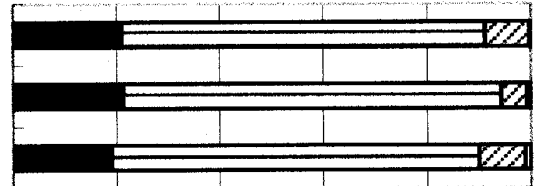

$\begin{array}{llllll}0 \% & 20 \% & 40 \% & 60 \% & 80 \% & 100 \%\end{array}$ 口閉める 日開ける 日分からない ロ未記入

図 2 火災時の空の開閉処理

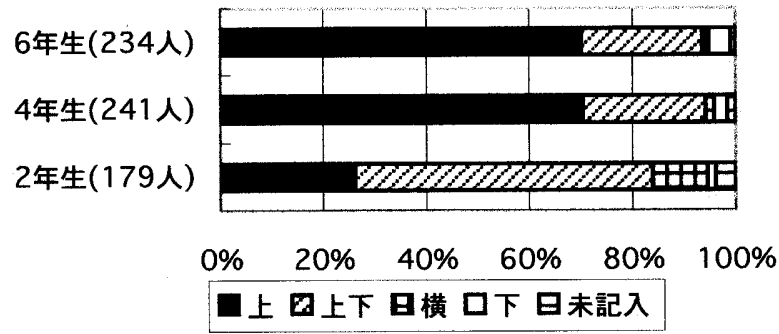

図 3 火災時の煙の流動 
る。先生や友達に火災を知らせる「報告」は $19 \%$ 、周りの人たち の様子を見て一緒に行動する「周囲同調」は追随行動に近いもの で $13 \%$ 見られた。また、自分で火を消しに行く「消火」は $3 \%$ で あった。このように 6 年生のアンケートによる避難行動予測は、

「即避難」「報告」「消火」のように積極的な行動を選択した者が 40\%、「指示待ち」のように慎重な行動を選択する者が $36 \%$ 、「教 室集合」「周囲同娚」のように他人に依存する行動を選択した者 が計 $20 \%$ と 3 つのイプに大きく分類出来る。

これに対して 2 年生は「指示待ち」を選択した者が $36 \%$ で最も 多く、次いで「教室集合」 $29 \%$ 、「周囲同調」 $12 \%$ 、「報告」 $11 \%$ 、 「即避難」 $8 \%$ と続く。「教室集合」タイプは、まず先生やクラス の友達に伝える、あるいは集団で集まることが行動の基本になっ ている。あくまでも紙面上のアンケート結果の範囲に限定される が、判断能力の未熟な年齢層であり、自己判断ができず適切な指 示がない場合には危険回避が遅れる可能性が高い。「周囲同調」 も含めると他人に依存する選択肢を選んだ児童は 2 年生では全体 の4割強がこれを占めた。いずれにしても児童は多様な行動パタ ーンを選択しており、実際の火炎現場での行動予測は容易ではな い。

以上の結果は、いずれの学校も避難訓練において「静かに放送 を聞き、その指示に従いなさいといった指導をしていることが、 児童の回答に影響していると考えられる。従って、学校では火災 時に迅速で適切な指示を出す必要があるといえる。

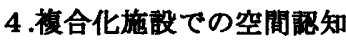

自らがおかれている複合施設の建築空間の全体像を十分理解し ているかどうか、避難上判断のポイントとなる火災室や階段の位 置など正確に認知しているかどうかは、火災時に単独で避難経路 を選択する場合の重要な判断材料である。複合化された他の公共 施設の認知率と、施設全体の認知率を取り上げる。

\section{1 複合施設の証知率}

同一建物内に学校以外の他の公共施設が複合された場合、児童 は学校以外の用途に使われている空間をどの程度認知しているか、 その認知率を示したものが図 5 である。全体を概観すると認知率 のばらつきが大きいことが読み取れる。

例えば $\mathrm{N}$ 小において、幼稚園が $60 \%$ 程度の認知率であるのに対 して社会教育施設が 15\%程度と明らかな差がみられる。ここでは、 小学校は地下 1 階から地上 5 階までに配置されており、2 または 3 階の教室にいる子どもたちにとって 2 階にある幼稚園は日常的 に認知しやすいと考えられる。一方 $7-9$ 階にある社会教育施設 は同一建物内といえどもなじみがない。そうした空間配置が認知 率の違いに表れていると考えられる。

同様に D 小では、2-5 階に学校があり、1階にある幼稚園に

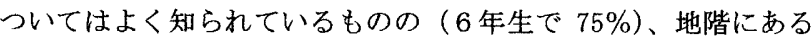
社会教育施設についてはほとんど認知されていない（6年で $10 \%$ に満たない) $\mathrm{S}$ 小では、1階にある幼稚園の認知率が低いのに拘 わらず、5階にある児童館の認知率は高い。児童の昇降口は 2 階 に設定されており、1階にある幼稚園は子どもたちの日常動線か らは外れるために幼稚園の認知率は低い。しかし児童館は一部の 子どもたちにはよく利用されており、学校上部の 5 階に設置され

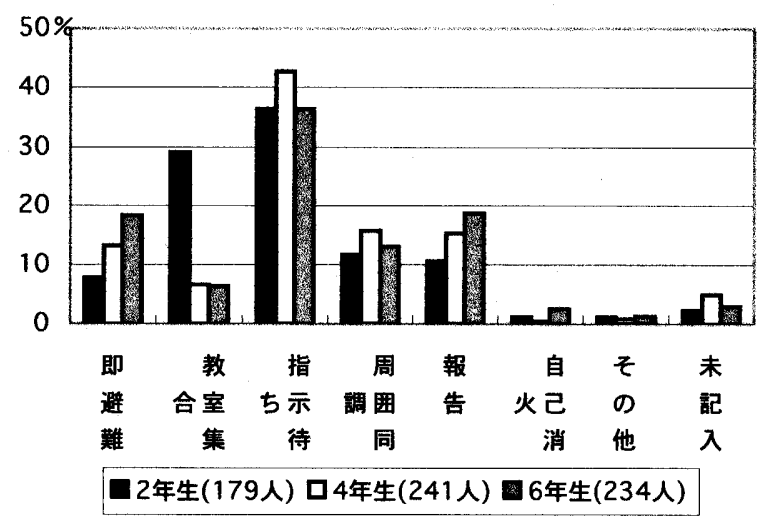

図 4 火災時の判断・行動

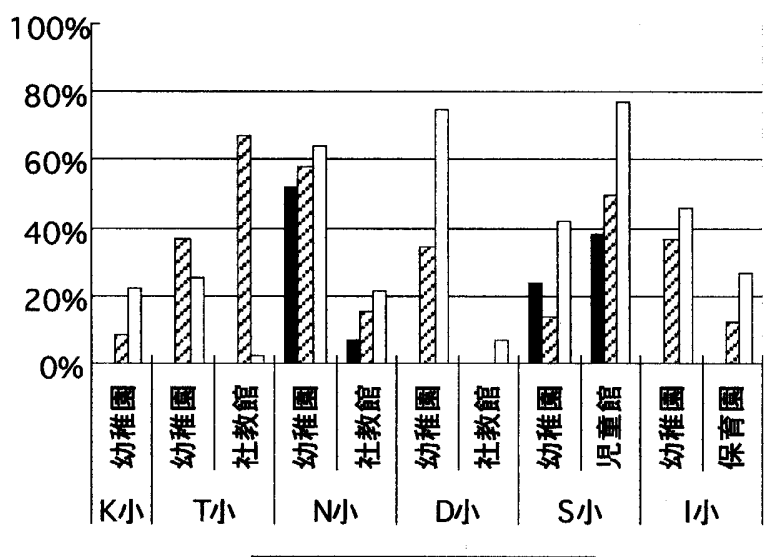

2年生口 4年生口 6年生

図 5 児童の複合施設の認知率

ているのに認知率は高いといえる。

I 小においては、幼稚園が 1 階、保育園が 1 ～ 2 階にあり階数 配置としてはほぼ同条件であるが、幼稚園に比べて保育園の認知 率が低い。これは、幼稚園のゾーンは小学校と空間的に連続して おり児童が自由に出入りできるが、保育園は扉を挟んでゾーンが 区切られており、通常児童は保育園ゾーンには足を踏み入れるこ とができないためと推測できる。

このように同一建物内の複合施設の認知率の高低は、学校ごと の個別の事情が強く影響しており、ばらつきが生ずるものと考之 られる。日常動線から外れている、日常的交流の機会がない、異 なるフロアにある、などの理由で、同一建物にありながら認知率 が高くならないと考えられる。

\section{2 複合化施設全体の䬺知率}

$2 つ$ つ学校を取り上け゚その空間認知の傾向を探る。図 7、9 のように空間認知の程度を 5 段階で示す。

1) D 小の空間認知率

4 年と 6 年の空間認知率を図 7 に示した。 3 階に教室を持つ 4 年生は全体的にフロアごとの認知率にかなりの差がある。地階に 設けられた社会教育施設や福祉施設についてはほとんど認知され ていない。これらの施設は日常的な交流を全く行っていないとい う点、また地階に配置されている点がそうした結果につながって 


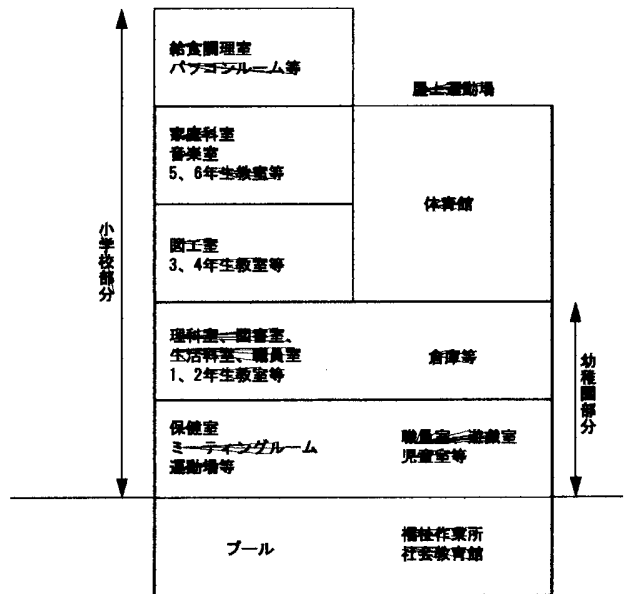

図 6 D 小学校断面略図
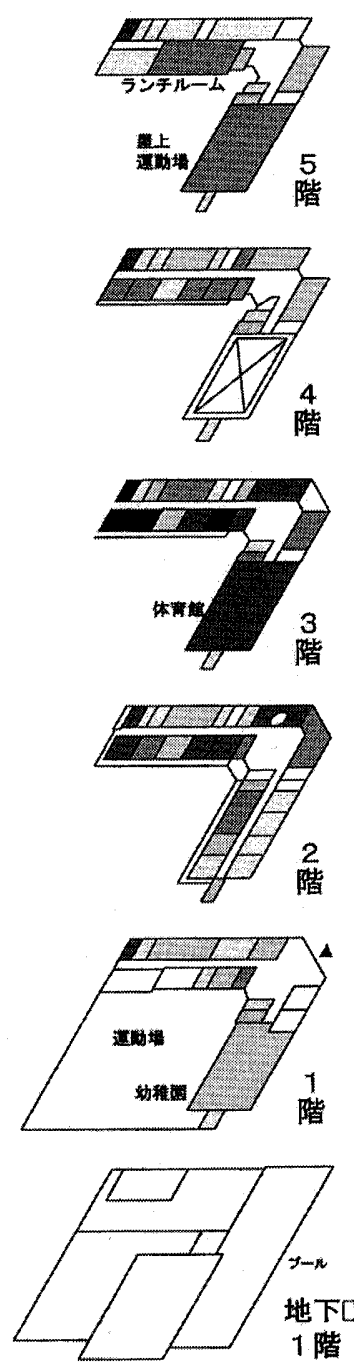

4年生
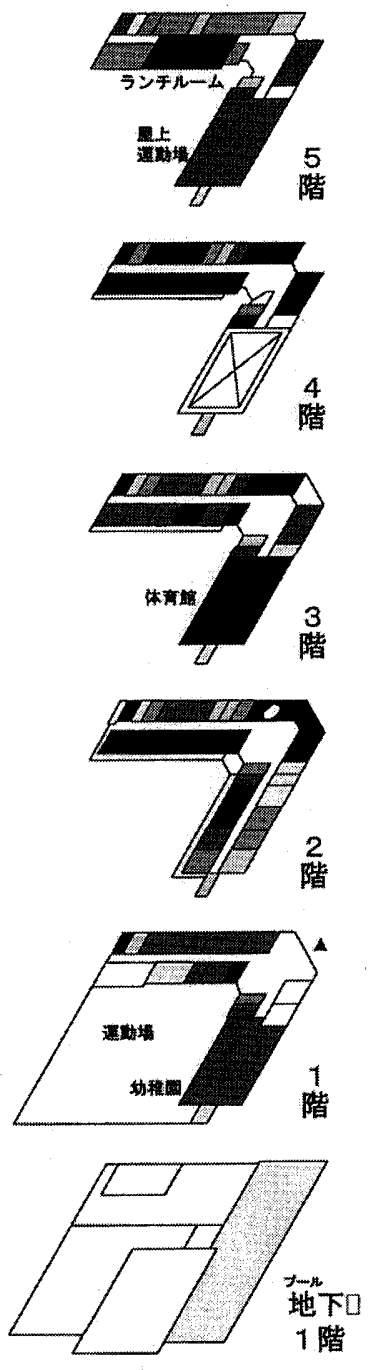

6年生
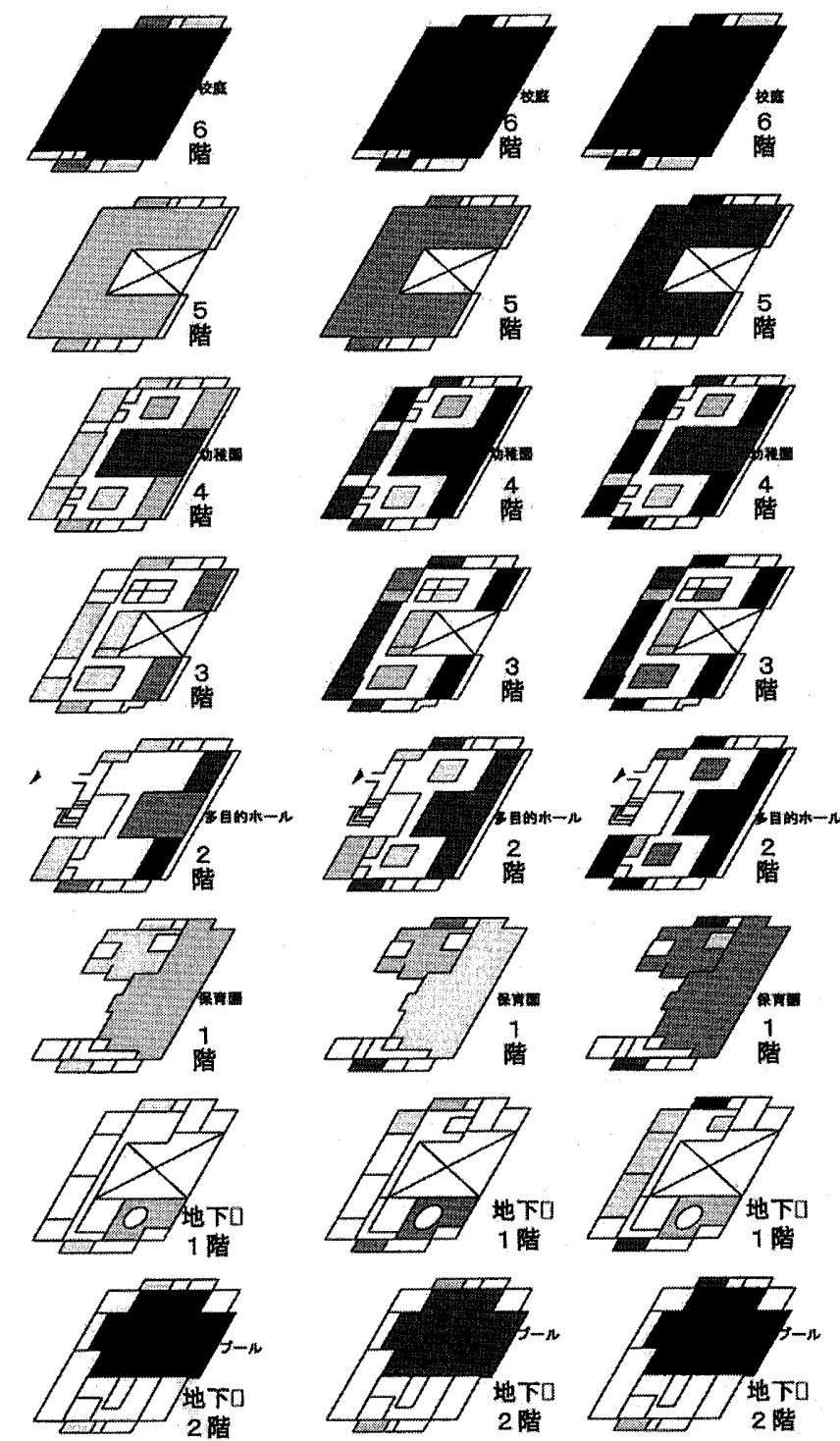

2 年生

4 年生

6 年生

図 9 S 小学校学年別認知マップ 
いると考えられる。教室の上の階については、5階のランチルー ムと運動場はよく認知されているが、その他の認知率は低い。自 室のある 3 階に偏った空間認知である。

6 年生は教室のある 4 階だけでなく、学校全体のフロアをよく 認知している。ただし、地階についてはこの学年もほとんど認知 しておらず、地上階に偏った空間認知であることがわかった。

2）S 小の空間認知率

$\mathrm{S}$ 小の空間認知率を図 9 に示した。地下 2 階地上 6 階で「幼稚 園」「児童館」「図書館」を複合している。この学校は、特別教室 の開放が積極的に行われており、一般市民が学校内に入り込む機 会が多い一方で、逆に学校サイドからも複合施設の利用をすすめ ており、児童の複合施設の利用頻度は高い。また、児童のエレベ 一ター利用に制限がなく、他の施設との行き来についても制約が ない。したがって複合施設の認知率も他校と比べて高い。

2 年生は全体として空間認知が断片的である。 2 年教室がある 2 階を中心に、温水プールのある地下 2 階、体育館のある 4 階、 屋上校庭のある 6 階に認知が偏っている。アプローチが 2 階にあ るためか、1 階の保育園はあまり認知されていない。4 年生にな ると教室が 3 階に移り、3 階を中心としてアプローチ階以上の階 と、地下 2 階はよく理解している。 2 年生同様、 1 階の保育園と、 厢房しかない地下 1 階部分はほとんど認知されていない。6 年生 は 4 階に普通教室があり、 4 年と比較しても全体的に認知率が高 い。ただし 1 階については $50 \%$ 程度の認知率にとどまっている。

\section{5.避難経路の選択傾向}

\section{1 学年の違いと避難経路選択}

火災時の適切な避難経路の選択には総合的な知識や判断などが 必要である。火災室から出た煙によって避難が難しい階段を児童 が回避できるかを知るために、ここでは自分の教室より下階にあ り、日常経路に近い階段付近に火災室を想定した。原則として、

1) 複数ある階段のうち安全な階段清6) を選択したか、2）火災 室に接近する経路を避けているか、3）避難場所に到達できるか が、回避経路選択のポイントである。

図 10 は学校別学年別の回避率注7) を示したものである。最も 判断力が高いと考えられる 6 年生をみてみると、I 小のように回 避率 $40 \%$ 程度の学校から、T 小のように全員安全に回避できる学 校まで様々である。学校の配置平面、クラスルームの位置、想定
火災室の違いによって単純な比較はできないが、おおむね、学年 が高くなるにつれ回避率は高くなる傾向がある。しかし、6 年生 であっても 10 人中 3 人は火災時に単独の避難ができない可能性 があるといらことである。4 年生になるとさらに回避率は低下し 平均 50\%程度となる。2 年生に関しては調查校が 2 校のみであっ たが、これよりさらに低くなることが考えられる。

以上のように概ね学年が高いほど回避率が向上する傾向は見ら れるものの、同じ学年でも回避率の数值はかなりばらつきがあり、 それぞれの学校の特性が反映されている。

\section{2 回避率と空間衿知率との関保}

2 方向避難の観点から、児童には回避すべき危険な階段と安全 な階段とを判別する能力が問われる。このことは、空間をよく理 解していることが危険な階段を回避して避難経路を選択すること と関連していると想定される。そこで、クラス単位で空間認知率 （施設全体の認知率と 1 階フロアの認知率）と回避率との関係を 調べた（図 11）。まずは複合化施設全体の空間認知率と回避率と の関係については、認知率が $50 \%$ 超える比較的高いクラスでは 回避率も高い傾向にあるが、認知率が低い群では回避率のばらつ きがかなり大きく、全体として両者の関係性は明確ではない（相 関係数 0.282)。次に地上階の 1 階フロアの認知率と回避率との関 係では、全体の空間認知率の比べるとより強い相関関係が見られ （相関係数 0.557）何らかの関係性の可能性を示している。しか し、認知率の高低にかかわらずどの認知レベルでも回避率にクラ スによって 40\%程度の差があることも事実であり、さらなる分析 が必要となろう。

\section{3 避難経路の選択と空間祅知}

4.2 で学校全体の認知率を取り上げた D 小と S 小を対象に、回 避率との関係を分析する。

1）D 小： 4 年は 3 階、 6 年は 4 階に教室がある。いずれも 2 階 にある理科室を火災室と想定したが、理科室に近いメイン階段 (昇 降口と教室を結ぶ距離が最短の階段）を避難経路として使わない という判断ができたか否かが、回避率の差（4年 $45 \% 、 6$ 年 $73 \%$ ) となった。避難経路としては 4 つの階段が利用可能であるが、平 面と垂直方向の位置関係を明確に理解できなければ、階段の選択 は容易でないと想像される。

2) $\mathrm{S}$ 小: 2 階の 2 年、 3 階の 4 年、 4 階の 5 年に対して、いず れも地下 1 階にある府房を火災室として想定した。回避率は、2

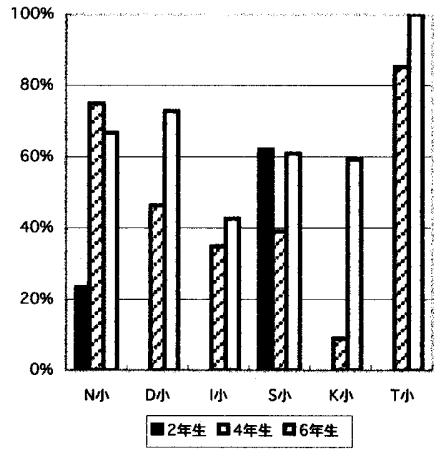

図 10 火災時の学年別回避率
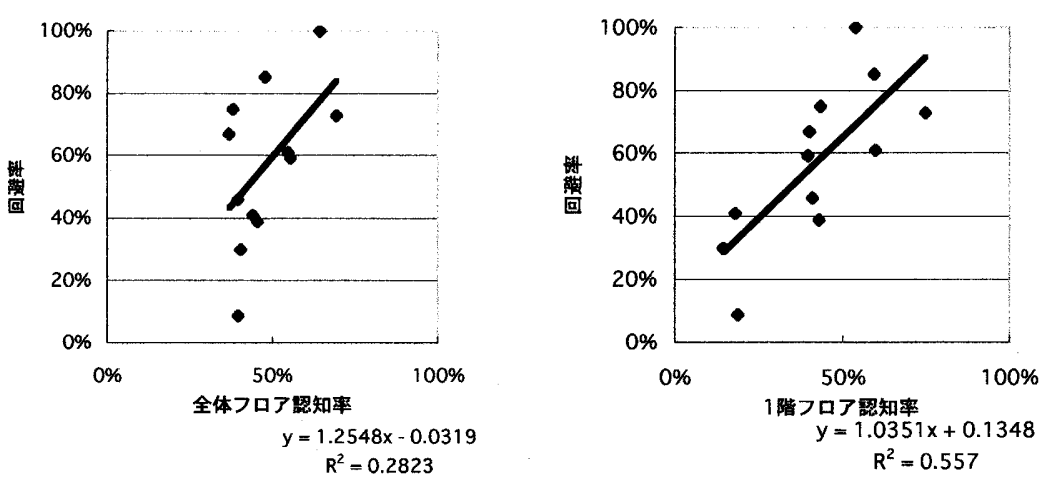

図11 フロア認知率と回避率の関倸 
年・6 年がほぼ同じで $60 \%$ 程度、 4 年が約 $40 \%$ である。 2 年の回 避率が良いのは、日常使う階段が安全階段と一致したためであろう。 逆に 4、6 年は日常よく使う階段が危険階段となり、このような学 年間の逆転現象が説明できる。 $\mathrm{S}$ 小の場合平面的にはわかりやすい 構成で空間認知率は高いと予想されるが、階段を選択する判断力に 欠ける結果となっている。

3 ）その他: $\mathrm{N}$ 小の 2 年生と $4 \cdot 6$ 年生とでは明らかな回避率の差 が見られる。2 年生では教室值下の職員室を火災室と想定しており、 日常的に使用頻度の高い昇降口に近い階段を選択する傾向が強く、 適切な避難経路の選択がなされなかった。逆に 4 年以上では空間認 知の高さが、適切な経路選択に結びついていると考えられる。T 小 での回避率の良さは、日常利用する階段が安全階段と重なっている ことで説明できる。

\section{6.まとめ}

本研究では、学校複合化施設における子どもの火災避難に関する 防災教育上の課題を明らかにするために、東京都内の 5 層以上の学 区複合化施設の児童生徒を対象に調査を行った。その要点は以下の 通りである。

1）東京区部の小中学校では、60 年代より他の公共施設を同一敷地 内に併設する事例が見られ、80 年代以降、同一建物で 5 層以上の学 校複合化施設が出現し始める。

2 ）火災時の空の開閉に関しては、小学生ではどの学年も約 $20 \%$ の 正解率にとどまる。煙流動に関しては小学 2 年生が $30 \%$ 程度、以降 $60 \%$ 程度で頭打ちとなり知識の獲得が十分ではない。

3）火炎時の単独避難行動については、「指示待ち」の子どもが $40 \%$ 程度で最も多いものの、他の子どもは様々な行動（即避難、教室集 合など）をとる可能性がある。

4) 複合施設については、その施設と子どもたちの日常動線との関 係、設置されるフロアと教室フロアとの関係、日常的交流の有無な ど、学校毎の特有な条件によって全く認知率が異なる。学校の全体 像について、低学年は自分の教室のあるフロアと日常使用頻度の高 いスペースのあるフロアに空間認知が偏るが、高学年ほど、空間認 知が全般に及ぶ。

5 ）避難経路の選択については、概ね学年進行にしたがって適切な 澼難経路をとれる傾向は見られるものの、日常よく使う階段を避難 時にも使う傾向が見られた。また、危険な階段を回避する回避率は、 施設全体のフロアの認知率よりも 1 階部分の認知率との相関関係が 強い傾向にある。垂直動線と平面構成との関倸が正確に理解されて いることが適切な経路選択につながる。

以上のように、学校複合化施設では学校空間の全体像が認知され にくいこと、防災知識の浸透が十分でないこと、安全な避難経路選 択に関して個別の事情が影響している実態を明らかにした。

\section{謝辞}

東京都の各小学校・中学校では調査にあたり、校長先生を始めと して教職員、児童の皆様に貴重な時間を割いてご協力を賜りました。 ここに梁謝の意を表します。なお、この研究は、文科省科研費によ る支援を受けたものです。

\section{考文献}

1）代表研究者建部謙治：子供の災害対応能力とその要因分析 平成 11 年 度 12 年度科学研究費補助金 (基盤研究 (C) (2)) 研究成果報告書 11650641、2001

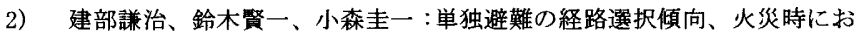
ける学校の避難計画に関する基礎的研究 その 1、日本建築学会計画系 論文集、No. $515 、$ pp. 159 164、1999. 1

3）鈴木賢一、建部萧治：児童の学校空間認知と避難経路選択、学校におけ る児童の火災避難行動に関する基礎的研究 その 2、日本建築学会計画 系論文集、No. 522、pp. 201～206、1999.8

4) 建部謙治、鈴木賢一：火災知識・行動判断の避難経路選択一の影響、 学校における児童の火災避難行動に関する基礎的研究 その3、日本建 筑学会計画系論文集 No. $556 、$ pp. $177 \sim 182 、 2002.6$

5）上野淳、本野純：公立小・中学校と地域公共施設の複合化事例におけ る建築計画と管理・運営の実態、日本建築学会計画系論文集 No. 493 pp. $117 \sim 124 、 1997.3$

6) 斎尾直子、藍澤宏、土本俊一、村山直樹：公立小・中学校の地域施設 としての機能複合化に関する研究、日本建築学会計画系論文集 No. 523 pp. 131 138、1999. 9

7）大野隆造、串山典子、添田昌志：上下方向の移動を伴う経路探索に関 寸る研究、日本建築学会計画系論文集 No. 516 pp. 87 91、1999.2

8）吉岡竜巳、建部謙治、鈴木賢一、ストレスと避難誘導が児童の避難行動 に与える影響について、平成 16 年度日本建築学会大会 (北海道) 学術講 演梗概集 E-1 建築計画 I、pp. 835-854、2004. 9

注

1) 同一建物内、または同一敷地内に学校施設と他の社会教育施設、文化 施設、スポーツ施設、その他の公共施設等を平面的あるいは立体的に共 存・融合させたもの。

2）同時期に中学校 2 校の生徒 377 人（1 年生 : 112 人、 2 年生 : 124 人、 3 年生 : 141 人) に対しても同様の調查を実施したが、ここでは小学校 のみを扱う。

3) 空間認知率とは、調査対象者のうちある空間を認知している者の割合 を示す。ここでは、平面図上に正確に室名を記述できた者の割合を示し ている。

4）たとえば千代田区では、児童生徒数の減少に伴い1993 年に 14 校あっ た小学校を 8 校に統廃合している。ここでの複合化の目標は、(1)地域コ ミュニティセンターとしての役割(2)生涯学習(3)国際化・情報化(4)災害時 に対态できる施設を目指したものである。千代田区では 2003 年を最後 に、他の区と同様財政難から新たな建設の予定は立っていない。

5 ）火事が起きたときに公はどうするべきか」の問いの正解については、 建築基準法上の解釈、あるいは火災の状況により判断が異なる場合があ る。ここでは、(1)学校が指導している内容、(2)所轄の消防署の意見、(3) 参考文献（文部省監修、教職員のための防災事典、日本体育・学校健康 センター、1999年 3 月）を参考に、正解を「閉める」と決めている。

6）「安全な階段」とは、火災発生室から離れており火災の影響を受けず に安全に避難できる階段のこと。

7 ）回避率とは、（安全な階段を避難経路として選択し避難場所に到達する 経路を記入した人数／調查対象人数） $\times 100 \%$ で示される数值である。

（2004年10月 10 日原稿受理， 2005 年 6 月 3 日採用決定） 